\title{
Diagnoza spektrum autyzmu u osób dorosłych jako biograficzny przełom
}

\begin{abstract}
STRESZCZENIE
Prezentowane badania dotyczą nieobecnego w dostatecznym stopniu w literaturze naukowej wątku dorosłych osób z diagnozą zaburzeń ze spektrum autyzmu. Ich podmiotem uczyniłam osoby szczególne: takie, które swoją diagnozę otrzymały będąc osobami dorosłymi. W centrum mojego badawczego zainteresowania znajdują się ich biografie. Analiza uzyskanych wywiadów narracyjno-biograficznych skoncentrowana jest przede wszystkim na strukturze biograficznej zwanej biograficznym przełomem. W narracjach dorosłych osób ze spektrum autyzmu diagnoza jawi się jak punkt zwrotny w biografii, który wywiera zasadniczy wpływ na życie nosicieli opowieści poprzez zmianę jego biegu i/lub transformację tożsamości.
\end{abstract}

\section{Słowa kluczowe:}

zaburzenia ze spektrum autyzmu (ASD), dorosłość, badania biograficzne

\section{ABSTRACT}

The research presented regards the issue of adults with diagnosed autism spectrum disorder, the presence of which in the scientific literature has been insufficient so far. For the object of my research I have chosen special people: individuals who were diagnosed with the autism spectrum disorder as adults. Their biographies are the focus of my research interest. In the analysis of the biographical narratives I obtained, my interest is centred primarily on the biographical structure referred to as the biographical

1 Sabina Pawlik, Wydział Pedagogiki i Psychologii, Uniwersytet Śląski, Polska, e-mail: sabina. pawlik@us.edu.pl. 
breakthrough. In the narratives of adults with autism spectrum disorder, the diagnosis appears as a turning point in their biography, exerting a significant impact on the life of the story protagonists by changing its course and/or transforming their personal identity.

\section{Keywords:}

Autism Spectrum Disorder (ASD), adulthood, biographical research

\section{WSTĘP}

Prezentowany tekst dotyczy nieobecnego w dostatecznym stopniu w literaturze naukowej wątku dorosłych osób z diagnozą zaburzeń ze spektrum autyzmu. Pojawiające się opracowania najczęściej dotyczą dzieci, a temat osób dorosłych pozostaje wciąż prawie niezauważony. Potwierdzają to autorzy raportu Ogólnopolski Spis Autyzmu, stwierdzając, że dorosłe osoby ze spektrum „to grupa rzadziej, niż dzieci z tym zaburzeniem, uwzględniana w badaniach naukowych, rzadziej obejmowana kompleksową i dostosowaną do ich potrzeb pomocą, rzadziej wreszcie pojawiająca się w świadomości społecznej. Według badań CBOS (2015), jedna piąta Polaków (21\%) uważa, że autyzm dotyczy jedynie dzieci, kolejne 12\% nie wie, czy to zaburzenie może występować u dorosłych, a 15\% w ogóle nie słyszało o autyzmie” (Płatos, 2016, s. 23).

Zagadnieniem w ogóle nieporuszanym w polskich badaniach jest sytuacja tych, którzy swoją diagnozę zaburzeń ze spektrum autyzmu otrzymali dopiero w okresie dorosłości. Są to zwykle osoby z łagodnym nasileniem objawów, urodzone na początku lat 90. XX wieku i wcześniej, u których, ze względu na brak kryteriów diagnostycznych (Zespół Aspergera znalazł się w klasyfikacji DSM-IV dopiero w 1994 roku), ignorowano mniej nasilone niż w autyzmie objawy (Sławińska, 2014, s. 305). Sytuacja zaczęła zmieniać się dopiero z rozszerzeniem definicji autyzmu w pierwszej połowie lat 90. XX wieku, kiedy dzięki opracowaniu kryteriów zespołu Aspergera do zaburzenia zostało włączone większe grono osób (również tych z łagodnym nasileniem objawów) (Por. Płatos, 2018, s. 110).

\section{OSOBY ZE SPEKTRUM AUTYZMU ZDIAGNOZOWANE W DOROSŁOŚCI}

Aby lepiej ukazać kontekst istotę i przyczyny uzyskania diagnozy autyzmu w dorosłości, konieczne jest zwrócenie uwagi, że autyzm jest grupą zaburzeń, które różnią się od siebie nasileniem poszczególnych objawów, stanowiąc bardzo niejed- 
norodną kategorię. Osoby z tak postawioną diagnozą mogą różnić się między sobą nie tylko stopniem funkcjonowania, ale również licznymi, współwystępującymi trudnościami natury fizycznej lub/i psychicznej (Buława-Halasz, 2015, s. 73). Do spektrum autyzmu zaliczyć można takie zaburzenia, jak: autyzm dziecięcy, zespół Aspergera, autyzm atypowy czy inne całościowe zaburzenia rozwoju. W najnowszej klasyfikacji zaburzeń psychicznych Amerykańskiego Towarzystwa Psychiatrycznego DSM-V wszystkie wymienione terminy zastąpiono zbiorczą jednostką zaburzeń ze spektrum autyzm (Autism Spectrum Disorder; w skrócie ASD) (Płatos, 2016, s. 11). Najwięcej kontrowersji powstało wokół usunięcia z oficjalnej klasyfikacji zespołu Aspergera. Miała na to wpływ naukowa dyskusja na temat różnic między autyzmem wysokofunkcjonującym (HFA) a zespołem Aspergera (ZA) właśnie. Anna Sławińska (2014, s. 305), powołując się na Erica Schoplera (1996, s. 108-110), zauważa, że „powstał pogląd, iż wyodrębnianie ZA, jako oddzielnej jednostki nozologicznej jest zbyteczne, gdyż można go utożsamić właśnie z HFA - formą autyzmu ze słabo nasilonymi objawami”. Za sprawą kryteriów diagnostycznych DSM - V zarówno ZA jak i HFA zalicza się do zaburzeń ze spektrum autyzmu z łagodnym ich nasileniem. Właśnie takie nasilenie objawów reprezentują osoby, u których diagnoza postawiona została dopiero w dorosłości.

Literatura wymienia kilka przyczyn takiego stanu rzeczy. Z ustaleń Michaela Davidovitcha i innych (2015), którzy przeanalizowali 42 badania przeprowadzone w okresie ostatniego dwudziestolecia, wynika, że wśród najważniejszych przyczyn diagnozy autyzmu postawionej w dorosłości wymienić można:

- łagodne nasilenie objawów autyzmu - zespół Aspergera rozpoznawany jest później, przypuszczalnie z powodu braku opóźnień językowych i/lub łagodniejszego nasilenia cech zgodnych z pozostałymi kryteriami diagnostycznymi;

- zaniedbania w zakresie badań przesiewowych w kierunku zaburzeń ze spektrum autyzmu;

- niską świadomość lekarzy na temat zaburzenia i wynikające z tego bagatelizowanie pierwszych objawów autyzmu zauważonych przez rodziców;

- niską społeczna świadomość na temat objawów autyzmu;

- nieprawidłową diagnozę we wczesnym dzieciństwie, przede wszystkim dotyczącą specyficznych zaburzeń rozwoju mowy i języka (Davidovitch i in., 2015, s. 227).

Do wymienionych powodów warto dodać jeszcze płeć. U kobiet zaburzenia ze spektrum autyzmu są trudniej rozpoznawalne, gdyż skuteczniej maskują one deficyty w sferze społecznej (Sławińska, 2014, s. 305; por. również Rynkiewicz, Łucka, Fryze, 2012), dlatego pozostają często niezdiagnozowane lub diagnoza nastąpiła zbyt późno. 
Powody, dla których osoby dorosłe poszukują rozpoznania, są bardzo różne. Niektórzy czynią to pod wpływem diagnozy spektrum autyzmu u ich własnych dzieci, zauważywszy, że w dzieciństwie wykazywały podobne cechy jak ich potomstwo. Według Atwooda (2007) 46\% rodziców dzieci z łagodnym nasileniem objawów spektrum autyzmu wykazuje podobny profil zachowań i cechy ASD (za: Rynkiewicz, Łucka, Fryze, 2012, s. 44). Bywa również, że na diagnozę autyzmu zostają skierowani przez terapeutę lub lekarza. Zdarza się także, że osoby szukając wytłumaczenia swoich problemów emocjonalnych, relacyjnych i zawodowych same decydują się poddać diagnozie.

Często pierwszym krokiem ku diagnozie specjalistycznej osób dorosłych jest ich autodiagnoza. Simon Baron-Cohen wraz z grupa specjalistów z Cenrum Badań nad Autyzmem w Cambridge stworzyli test do określenia czynnika AQ (AutismSpectrum Quotient), którego głównym celem było ułatwienie wstępnego badania w kierunku rozpoznania zaburzeń typu autystycznego. Test AQ jest na tyle prosty, aby każdy był w stanie sam go na sobie przeprowadzić (http://niegrzecznedzieci. org.pl/asperger/zrob-sobie-test-czy-jestes-z-kregu-aspi/).

Niezależnie od powodów, dla których osoba dorosła zdecydowała się poddać diagnozie w kierunku autyzmu, fakt ten ma duże znaczenie dla przebiegu jej dalszego życia i kształtowania własnej tożsamości, która, jak twierdzi Anselm Strauss: ,jest związana z brzemiennymi w skutki ocenami wystawianymi nam przez nas i przez innych” (Strauss 1997, s. 11, za: Treichel, 2012, s. 577).

Formalne rozpoznanie ASD uzyskane w dorosłości ma swoje społeczne konsekwencje, które mogą okazać się nie mniejszym obciążeniem niż same objawy zaburzenia, stanowiąc „drugą chorobę” (Świtaj, 2009, s. 377). Mimo, iż osoby te zwykle w swoim życiu nie potrzebują specjalnej troski i wsparcia (przez większość swojego życia żyły bez diagnozy), otrzymują stygmat osoby z „deficytem”. Atrybut, jakim staje się formalna diagnoza, może być dla nich przyczyną społecznego piętna, ponieważ zaczynają być postrzegani jako naznaczeni, niepełnowartościowi lub mniej pożyteczni społecznie (Goffman, 2005, s. 32-33, za: Świtaj, 2009, s. 378).

Piętno takie bez wątpienia wywiera negatywny wpływ na osoby je posiadające. Jego najbardziej oczywistą konsekwencją jest bezpośrednie odrzucenie społeczne i dyskryminacja. Otrzymanie „oficjalnej etykiety” może prowadzić również do internalizowania i odniesienia do siebie negatywnych społecznych przekonań i stereotypów, czego skutkiem jest poczucie wstydu, spadek samooceny czy utrata wiary we własne siły.

Aby uniknąć negatywnych konsekwencji, osoby ze „stygmatyzującym atrybutem” stosują różne strategie obronne, wśród których można wymienić: ukrywanie diagnozy, izolację i społeczne wycofanie, edukowanie innych bądź aktywne 
zaangażowanie w zmianę nieprzychylnych postaw społecznych (Świtaj, 2012, s. 380). Piotr Świtaj (2012) zauważa, że wymienione sposoby radzenia sobie z piętnem chronią wprawdzie naznaczone jednostki przed niektórymi aspektami stygmatyzacji, ale mogą mieć również swoje negatywne skutki: próby edukowania innych mogą zwiększać ryzyko odrzucenia i dyskryminacji, wycofywanie się z kontaktów społecznych zawęża sieci społeczne i powoduje izolację, ukrywanie piętna sprawia, że konieczne staje się stałe kontrolowanie sytuacji, które dla innych mają charakter rutynowy (s. 380).

Aby przeciwdziałać stygmatyzującym skutkom rozpoznania, można rozważyć zastąpienie kategorialnego podejścia do diagnozy podejściem wymiarowym, ujmując ją jako opis profilu objawów osadzających się na pewnym - obejmującym również normę - continuum. Wydaje się, że taką propozycję wysuwają Baron-Cohen i współpracownicy (Baron-Cohen, Wheelwright, 1999, s. 484-490, za: Rynkiewicz, Łucka, Fryze, 2012, s. 44) od wielu lat używając w piśmiennictwie nazwy „stan ze spektrum auztymu” (Autism Spectrum Condition, ASC). Jej koncepcja zakłada, że nie każda osoba prezentująca cechy autystyczne i będąca w spektrum autyzmu jest osobą zaburzoną. Przyjmując takie założenie nazwa „stan ze spektrum autyzmu” w przeciwieństwie do „zaburzeń ze spektrum autyzmu” nie ma konotacji negatywnie wartościującej społecznie. Diagnoza spektrum autyzmu w dorosłości może wówczas dla jej posiadaczy stanowić drogę do lepszego, bardziej świadomego życia:

- może pomóc w zrozumieniu przyczyn pojawiających się trudności;

- może skorygować wcześniejszą błędną diagnozę, co oznacza, że dostarczy narządzi do skutecznego rozwiązywania problemu;

- może pomóc w uzyskaniu dostępu do odpowiednich usług i korzyści;

- może dać przepustkę do „autystycznych społeczności”, które otwarte są tylko dla osób posiadających oficjalną diagnozę (społeczności internetowe, formalne i nieformalne grupy wsparcia);

- może stać się przepustką do przewartościowania dotychczasowego życia i daje możliwość identyfikacji z innymi osobami z autyzmem (http://www. autism.org.uk/about/diagnosis/adults.aspx, dostęp: 31.05.2018).

\section{NOTA METODOLOGICZNA}

Prezentowane badania wpisują się w nurt badań jakościowych w paradygmacie interpretatywnym, które badają konstruowaną przez ludzi, subiektywnie doświadczaną rzeczywistość społeczną (Piorunek, 2016, s. 8). Ukazują niepełną spraw- 
ność jako zespół czynników cechujących ludzką kondycję i poddają ją refleksji społecznej i egzystencjalnej (por. Rzeźnicka-Krupa, 2007).

Jak już zostało wspomniane, w centrum badawczego zainteresowania znajdują się biografie osób, którym diagnozę zaburzeń ze spektrum autyzmu postawiono w dorosłości. Celem badań była próba uchwycenia znaczenia diagnozy ze spektrum autyzmu dla nosicieli biografii oraz sposobu konstruowania ich tożsamości po jej uzyskaniu. Od lutego do maja 2018 roku przeprowadzone zostały cztery wywiady biograficzno-narracyjne (trzy wywiady z kobietami i jeden z mężczyzną) z osobami, które diagnozę spektrum autyzmu otrzymały w dorosłości. Urodziły się w Polsce pod koniec lat 70. lub w latach 80. XX wieku, kiedy diagnostyczna i społeczna świadomość autyzmu była niewielka. W związku z tym w dzieciństwie nie otrzymały żadnej diagnozy bądź otrzymane rozpoznanie było błędne.

Zastosowaną metodą była metoda badań biograficznych, która od kilku dekad przeżywa swój renesans (Kaźmierska, 2012, s. 9). Rozwija się nie tylko w socjologii, ale również w psychologii, historii, pedagogice. Wiąże się to z dowartościowaniem metod jakościowych, które wypracowują sobie w naukach społecznych coraz mocniejszą pozycję (Kaźmierska, 2012, s. 10). Badania biograficzne dają, jak zauważa Martin Kohli (2012, s. 127), uzyskanie dostępu do życia społecznego w wyczerpującym stopniu, „od wewnątrz”, czyli „z perspektywy jego znaczenia i aspektów subiektywnych oraz jego wymiaru historycznego" (Kohli, 2012, s. 127).

Techniką badawczą był wywiad autobiograficzo-narracyjny, który w badaniach biograficznych jest podstawą do uzyskania wiedzy (Kaźmierska, 2016, s. 9). Uzyskana w jego wyniku narracja, jak zauważa Kaja Kaźmierska: „daje możliwości rekonstrukcji zarówno obrazu rzeczywistości, jak i jej interpretacji przez aktorów społecznych” (Kaźmierska, 2012, s. 9). Wywiad biograficzny pozwolił na odtworzenie przez narratorów procesów biograficznych, które kształtowały ich życie w kolejnych fazach biografii (por. Kaźmierska, 2012, s. 10).

Pierwszym podjętym krokiem badawczym była analityczna abstrakcja wszystkich przypadków. Następnie zastosowałam strategię porównania kontrastowego, biorąc pod uwagę cztery przypadki kontrastujące ze sobą w sposób minimalny (Schütze, 2012, s. 273), aby odsłonić najbardziej dla nich elementarne kategorie wspólne (Schütze, 2012, s. 273). Pozwoliło to na analizę struktury biograficznej zwanej biograficznym przełomem (por. Schütze, 2012, s. 273), jako jednej z podstawowych struktur procesowych wyróżnionych przez Fritza Schützego (2012, s. 158). 


\section{DIAGNOZA U OSÓB DOROSEYCH ZE SPEKTRUM AUTZYMU W PERSPEKTYWIE BIOGRAFICZNEJ. BADANIA WŁASNE}

Biograficzny przełom (metamorfozy, przemiany) odpowiada procesom biograficznym zogniskowanym na przemianie tożsamościowej. Może być efektem napotkania przez jednostkę nieprzewidzianych, nowych i wzbogacających możliwości życiowych (Rokuszewska-Pawełek, 1996, s. 44) lub wydarzenia, które wywiera na człowieka zasadniczy wpływ poprzez zmianę biegu życia lub tożsamości (Dobrowolska, 1992, s. 85). Związany jest z bardzo silnym przeżyciem psychicznym, zmieniając widzenie świata, stanowiąc krytyczne wydarzenie w biografii, a jego pojawienie się zmusza człowieka do przyznania ,że nie jestem tym samym, kim byłem, jaki byłem kiedyś” (Strauss, 2012, s. 532). Towarzyszą mu uczucia: zaskoczenia, szoku, rozgoryczenia, niepokoju, napięcia, zdumienia, zwątpienia w siebie, a także potrzeba wypróbowania nowego siebie, wynikająca z chęci odnalezienia się w nowej koncepcji własnej osoby (Strauss, 2012, s. 532).

Punkty zwrotne w biografii są bez wątpienia momentem, kiedy jej nosiciel musi zredefiniować swoją tożsamość, ponownie ją zrozumieć i osądzić.

Poniżej przestawiam trzy ujęcia, zawierające fragmenty zapisu narracji wszystkich narratorów, ukazujące znaczenia przypisywane diagnozie oraz sposoby (re)konstruowania swojej tożsamości po diagnozie.

\section{UJĘCIE I}

N 1: I ja też zaczęłam zauważać, że starszy $[\ldots]^{2}$ ma bardzo podobne zachowania do mnie w dzieciństwie. Poza tym, też mi przeszło tak przez myśl, że mam dwójkę dzieci, oba w spektrum, więc tak [...] no i zaczęłam się więcej dowiadywać, tak [...] diagnoza kobiet jeszcze leży w Polsce dosyć mocno [...], no i poszłam na tą diagnozę i wyszło, że mam zespół Aspergera, mmm [...]. I w tym momencie, kiedy dostałam diagnozę, naprawdę tak [...] spodziewałam się jej od dłuższego czasu, ale odsypiałam ją chyba ze trzy dni, bo się nagle okazało, że ja nie wiem, kim jak jestem, tak [...], gdzie jest moja tożsamość, a gdzie ja w tym (zlepku) mam znaleźć siebie. Chociaż ja już od paru lat w sumie żyłam po swojemu, ale zorientowałam się, że, kurcze, jestem między tym buntem a uległością [...] i że ciągle nie ma miejsca na moje pasje [...]. Też aktualnie zaczęłam parę dni temu psychoterapię. Dopiero po zdiagnozowaniu zespołu Aspergera dowiedziałam się [...], że ja powinnam, bo leki antyde-

\footnotetext{
2 () nawias oznacza pauzę w narracji.
} 
presyjne na mnie nie działały, że warto byłoby spróbować przeciwlękowych, które działają bardziej na osoby w spektrum. Dostałam taki lek, już jestem taka wyrównana emocjonalnie. Zaczęłam też trochę działać w kierunku takiej swojej przyszłości i w kierunku tego, żeby troszeczkę zmienić i połączyć to z tym, żeby zmienić sposób patrzenia na osoby w spektrum [...]. Nie ukrywam, że na tym mi przede wszystkim zależy.

Moment postawienia diagnozy zaburzeń ze spektrum autyzmu potraktowany został jako bodziec do przekonstruowania dotychczasowego życia. Tożsamość znajduje się jednak dopiero w fazie konstruowania. Diagnoza wprawdzie unieważniła to, co działo się przed jej uzyskaniem, jednak ostateczna odpowiedź na pytanie „kim jestem?” nie została jeszcze przez nosicielkę opowieści (Schütze, 2012, s. 172) udzielona. W opowieści odnajdujemy typową dla prezentacji biograficznej metamorfozy orientację narracyjną „bycia zdezorientowanym w sytuacji zawieszenia po utracie swojego starego poglądu na świat i właściwych mu kategorii, podczas, gdy nowy nie został jeszcze odkryty [...]” (Schütze, 2012, s. 181).

\section{UJĘCIE II}

N 2: Muszę powiedzieć, że bardzo dużo mi to (diagnoza) zmieniło, z tego powodu, że ja całe życie uważałem się za takq osobę bardzo nieudanq [...] i powiem tak, po diagnozie postanowiłem dać sobie jeszcze jedną szansę. Stwierdziłem, że po prostu nagle mi się zaczęło wszystko układać, zacząłem się interesować bardzo autyzmem [...] powiem szczerze, że gdyby nie diagnoza, tobym się dawno zastrzelił. Diagnoza była wydarzeniem pozytywnym z tego powodu, że ja się włączyłem w ten ruch self-advocacy, zacząłem pomagać ludziom. Później tak zupełnie wyszło niechcący, że dzięki diagnozie znalazłem pracę [...]. Znalazłem pracę i z tą pracą to było tak, że w moim mieście jest szkoła i ośrodek dla dzieci i młodzieży z autyzmem, oni organizowali konferencję [...] i oni mają cały czas problemy z nauczycielami i z opiekunami, bo większość ludzi jak słyszy autyzm, to sobie wyobraża Bóg wie co. Więc jest kłopot z kadrą. Moja znajoma też z ASD, bardzo działająca osoba, blogerka, też była zaproszona na konferencję i powiedziała organizatorom, że przecież mają gościa, który działa i jest z tego samego miasta [...] i potem jak się pani dyrektor dowiedziała, że jestem (wymienione wykształcenie), zapytała, czy ja jestem zainteresowany, żeby pracować w szkole [...]. Najpierw było tak, że prowadziłem wycieczki i później jak się okazało, że dzieciaki się ze mną świetnie dogadują, a ja z nimi, to od nowego roku zacząłem pracować i już w tej chwili drugi rok pracuję w szkole. 
W przytoczonym fragmencie wywiadu zostało ujawnione, w jaki sposób uzyskanie diagnozy doprowadziło do zmiany dotychczasowego życia. Dzięki diagnozie (i jej ujawnieniu) pojawiła się szansa na zmianę życia zawodowego (wcześniej narrator borykał się z dużymi problemami w tym zakresie). Zarówno diagnoza, jak i rozpoczęcie nowej pracy noszą znamiona wydarzenia przełomowego. Narrator przeżywa sytuację, w której następuje kumulacja kilku wydarzeń życiowych. Dzieje się tak dlatego, że jedno wydarzenie pociąga za sobą drugie (Dobrowolska, 1992, s. 85). Znajduje się w sytuacji, w której udaje mu się odegrać obcą sobie, ale ważną rolę i nieoczekiwanie dobrze jej podołać. Nosiciel opowieści nigdy wcześniej nie przypuszczał, że jest w nim takie potencjalne „ja” (Strauss, 2012, s. 534).

Orientację narracyjną charakteryzuje dynamika bycia poruszonym przez nowe rozwiązania dotyczące kształtowania własnej kariery zawodowej, pochodzące z odmiennych, obcych do tej pory (przed diagnozą) społecznych światów (Schütze, 2012, s. 181).

\section{UJĘCIE III}

N 3: Po sześciu miesiącach jedno spotkanie i panie nie miały absolutnie żadnej wątpliwości [...], stanęło na tym, że ja mam zaburzenie ze spektrum autyzmu [...]. Zaczęłam ją (diagnozę) bardzo mocno przyśpieszać z uwagi na to, że młodej robiło się coraz gorzej szkoła i tak dalej. Miałam takie poczucie, że jak się jej robiło gorzej, to szkoła i reszta próbowali jakoś tam mnie obarczać, tak, przyczynowością tego stanu rzeczy. Jakby nie wiedząc, jak można inaczej jej pomóc, szukali przyczyn w domu rodzinnym, oczywiście. Więc z drugiej strony dla mnie diagnoza autyzmu była formą obrony w sensie, że to nie jest tak, że ja jestem lewa jako matka, ale nasza rodzina funkcjonuje z definicji nieco inaczej, bo w tej rodzinie są wszyscy inni [...]. I faktycznie to się zmieniła i wyluzowała ta sytuacja, kiedy ja zaczęłam się wachlować swoim rozpoznaniem. I pokazywać, że hello, dzień dobry, „,o mi zrobicie, jak mnie złapiecie”. Formą obrony - żeby ktoś nie próbował mnie spakować w swój neurotypowy obrazek i ponieważ nasza rodzina się do tych neurotypowych ramek nie mieściła i nie mieści, i mieścić nie będzie, choćby nie wiem co. To nie próbowano mnie obciążać odpowiedzialnością za sytuację, jaka jest w rodzinie, czy za stan zdrowia dziecka, za który odpowiedzialności nie ponoszę, bo to jest nie z wychowania, tylko z genetyki i całej reszty innych uwarunkowań. Faktycznie się zmieniło sporo, jak się zaczęłam wachlować własnym rozpoznaniem, że ja też jestem autystyczna, nagle się okazało, że wow, ok, to, że ja nie jestem super wylewna emocjonalnie, jest w porządku; to, że moja mimika żyje sobie swoim życiem i generalnie wydaje się bezczelna 
i ironiczna wobec każdego, też jest w porządku, a wcześniej, kurcze, nie było, więc [...] dostałam w sumie sporo propsów w związku z diagnozą w gruncie rzeczy, przyzwolenie na inność przede wszystkim i dałam sobie to przyzwolenie też. Pozwoliłam sobie na bycie inną i się z tego powodu nie stresować, nie spinać.

N 4: Ale ta diagnoza mnie bardzo ucieszyła, bo właśnie też w tym kontekście tamtego związku... bo ja myślałam, że to jest wszystko moja wina albo że mnie mama nie nauczyła, bo sama nie umiała, albo że ja jestem jakaś głupa i inna, a potem się okazuje, że [...], że jestem w stuosobowej grupie dziewczyn takich jak ja i [...], i jestem tam kompletnie normalna, i... (diagnoza) wszystko mi wytłumaczyła, i właśnie odciążyła moich rodziców pod tym względem, głównie mamę, że ja z mamą mieszkałam. Mama też społecznie jest mało aktywna i ją w ogóle takie kobiece rzeczy nie wiem malowanie się w ogóle nie ma mowy ani gadanie o niczym. Ona jest księgową, uwielbia swój zawód i myśli precyzyjnie... więc też mogło być, że mama mnie nie nauczyła, bo sama jest nieogarnięta, a no... [...]

W przytoczonych fragmentach narracji, które ze względu na podobne znaczenia przypisywane diagnozie przez nosicielki opowieści zdecydowałam się ulokować w jednym ujęciu, zostało ukazane, w jaki sposób diagnoza zastępuje „inną”, gorszą etykietę (bycia złym rodzicem, dziwnym dzieckiem), zdejmując jej brzemię zarówno z autorek narracji, jak i ich otoczenia. Za sprawą diagnozy ukazały one światu „że nie są tym, kim oni myśleli, że są”, a przyczyna problemów jest inna niż mogło się na pozór wszystkim wydawać. Koniecznym stało się oficjalne zanegowanie swojej nieautystycznej tożsamości, które nastąpiło dzięki rozpoznaniu zaburzenia, aby wypracować porozumienie z samym sobą i z „resztą świata” (por. Strauss, 2012). Charakterystyczny w przedstawionej niżej orientacji narracyjnej jest sięganie po porady znaczących innych (w tym przypadku diagnostów) odnośnie do zagadek na swój temat, aby w innym świetle spojrzeć na problemy swoje i swojej rodziny (por. Schütze, 2012, s. 182).

\section{KONKLUZJE}

Puentując, sięgam ponownie do celu badań, poszukując punktów wspólnych zaprezentowanych narracji. U wszystkich nosicieli historii uzyskanie diagnozy miało znamiona wydarzenia przełomowego, na co wskazuje język przytoczonych narracji: 
- poszukiwania zmian we własnej tożsamości (por. Schütze, 2012, s. 181)

N 3: [...] Faktycznie się zmieniło sporo, jak się zaczęłam wachlować własnym rozpoznaniem [...], dostałam w sumie sporo propsów w związku z diagnozą w gruncie rzeczy, przyzwolenie na inność przede wszystkim i dałam sobie to przyzwolenie też [...].

- bycia poruszonym przez nowe rozwiązania pochodzące z odmiennych społecznie światów (Schütze, 2012, s. 182)

N 2: [...] Później tak zupełnie wyszło niechcący, że dzięki diagnozie znalazłem pracę $[\ldots]$.

- bycia zdezorientowanym w sytuacji zawieszenia po utracie swojego starego poglądu na świat i właściwych mu kategorii, podczas gdy nowy nie został jeszcze odkryty (Schütze, 2012, s. 182).

N 1: [...] Spodziewałam się jej od dłuższego czasu, ale odsypiałam ją chyba ze trzy dni, bo się nagle okazało, że ja nie wiem, kim jak jestem, tak [...], gdzie jest moja tożsamość, a gdzie ja w tym (zlepku) mam znaleźć siebie [...].

Dla osób udzielających wywiadów przemiana, jaka nastąpiła dzięki diagnozie, stanowiła bezsprzecznie jeden z etapów pracy biograficznej nad trajektorią (por. Rokuszewska-Pawełek, 1996, s. 45). Życie przed diagnozą było postrzegane jako pasmo nieszczęść i porażek, podczas gdy diagnoza dała nadzieję na lepsze życie i skłoniła do podjęcia pracy nad jego przemianą.

N 2: [...] Stwierdziłem, że po prostu nagle mi się zaczęło wszystko układać, zacząłem się interesować bardzo autyzmem, powiem szczerze, że gdyby nie diagnoza, tobym się dawno zastrzelił [...]

Perspektywa diagnoza jako piętna jawi się w przedstawionych narracjach niezwykle subtelnie. Z biografii można wnioskować, że jej nosiciele, aby uniknąć negatywnych konsekwencji posiadania ,stygmatyzującego atrybutu”, jakim wydaje się rozpoznanie autyzmu, stosowali różne strategie obronne, przede wszystkim:

- zawężania sieci społecznych poprzez zaangażowanie się w hermetyczne grupy tematyczne skoncentrowane wokół tematu autyzmu, oparte w dużej mierze na kontaktach on-line 
N 2: [...] Diagnoza była wydarzeniem pozytywnym z tego powodu, że ja się włączyłem w ten ruch self-advocacy [...].

- edukowania innych i aktywnego zaangażowania w zmianę nieprzychylnych postaw społecznych

N 1: [...] Zaczęłam też trochę działać w kierunku takiej swojej przyszłości i w kierunku tego, żeby troszeczkę zmienić i połączyć to z tym, żeby zmienić sposób patrzenia na osoby w spektrum [...]. Nie ukrywam, że na tym mi przede wszystkim zależy.

Wymienionym strategiom nie można jednak jednoznacznie przypisać wartości negatywnych.

Obie mogą prowadzić do pozytywnych skutków zarówno dla społeczeństwa (wzrost społecznej świadomości na temat autyzmu), jak i dla jednostki (możliwość identyfikacji z innymi osobami z autyzmem).

W zaprezentowanych narracjach najbardziej zastanawiający wydaje się fakt, że oficjalna diagnoza autyzmu, mimo tego, że zasadniczo nie zmieniła kondycji ani możliwości uczestników badań, zmieniła sposób, w jaki są społecznie postrzegani. Za sprawą diagnozy i przyporządkowania ich do konkretnej kategorii ich inność, ekscentryczność i dziwactwa zostały „usprawiedliwione” i stały się, jak za sprawą czarodziejskiej różdżki, możliwe do zaakceptowania przez otoczenie. Paradoksalnie rozpoznanie nie oznaczało dla narratorów, jakby się spodziewać, kolejnej etykiety, a było postrzegane jako uwolnienie od tej, którą do tej pory posiadali i uważali za bardziej uciążliwą i krzywdzącą wobec nich. Odrzucenie społeczne i dyskryminacja jawiły się im jako bardziej dokuczliwe przed niż po otrzymaniu diagnozy.

N 4: [...] Bo ja myślałam, że to jest wszystko moja wina albo że mnie mama nie nauczyła, bo sama nie umiała, albo że ja jestem jakaś głupa i inna, a potem się okazuje, że, że jestem w stu osobowej grupie dziewczyn takich jak ja [...].

N 3: [... W Więc z drugiej strony dla mnie diagnoza autyzmu była formą obrony w sensie, że to nie jest tak [...], że ja jestem lewa jako matka, ale nasza rodzina funkcjonuje z definicji nieco inaczej, bo w tej rodzinie są wszyscy inni (). I faktycznie to się zmieniła i wyluzowała ta sytuacja, kiedy ja zaczęłam się wachlować swoim rozpoznaniem [...]. 
Podsumowując, w centrum narracji znajdowały się życiowe doświadczenia narratorów, ich sposób rozumienia świata, prawo do odmienności oraz poszukiwanie własnej, unikalnej tożsamości (por. J. Rzeźnicka-Krupa, 2013). Zaprezentowane badania pozwoliły, aby każdy narrator - uczestnik społecznych wydarzeń - mógł opowiedzieć swoją małą, lokalną historię, podzielić się ze mną (słuchaczem) oraz pośrednio z czytelnikiem kawałkiem swojego świata. W moim przekonaniu pozwoliły również na coś więcej. Narracje osób ze spektrum autyzmu okazały się nie tylko historiami opisującymi daną rzeczywistość. Narracje stworzyły również język, w którym osoby opowiadają własne doświadczenia, a tym samym mogą otworzyć nowe drogi myślenia na temat autyzmu, pokazując nam „od środka”, czym jest jego doświadczenie, przez co realnie wpływają na kształtowanie wizerunku społecznego osób z autyzmem (Hacking, 2009, s. 1467).

\section{Bibliografia}

Attwood, T. (2007). The Complete Guide to Asperger's Syndrome. London: Jessica Kingsley.

Baron-Cohen, S., Wheelwright, S. (1999). Obsessions in children with autism or Asperger syndrome. Content analysis in terms of core domains of cognition. The British Journal of Psychiatry: The Journal of Mental Science, 175, s. 484-490.

Buława-Halasz, J. (2015). Emancypacja osób autystycznych. Wprowadzenie do zagadnienia. Interdyscyplinarne Konteksty Pedagogiki Specjalnej, 10, s. 73-87. DOI: https:// doi.org/10.14746/ikps.2015.10.05.

Davidovitch, M., Levit-Binnun, N., Golan, D., Manning-Courtney, P. (2015). Late Diagnosis of Autism Spectrum Disorder After Initial Negative Assessment by a Multidisciplinary Team. Journal of Developmental and Behavioral Paediatrics, 36(4), s. 227-234. DOI: 10.1097/DBP.0000000000000133.

Dobrowolska, D. (1992). Przebieg życia - fazy - wydarzenia. Kultura i Społeczeństwo, 2, s. 75-88.

Goffman, E. (2005). Piętno. Rozważania o zranionej tożsamości. Gdańsk: Gdańskie Wydawnictwo Psychologiczne.

Hacking, I. (2009). Autistic autobiography. Philosophical Transactions of the Royal Society B: Biological Sciences, 364(1522), s. 1467-1473. DOI:10.1098/rstb.2008.0329.

Kaźmierska, K. (2012). Wprowadzenie. W: K. Kaźmierska (red.), Metoda biograficzna w socjologii. Antologia tekstów. Kraków: Wydawnictwo Nomos.

Kaźmierska, K. (2016). Od redaktora: Proces transformacji w doświadczeniach biograficznych. Przegląd Socjologii Jakościowej, 2(12), s. 6-16. Pobrane z: http://www. qualitativesociologyreview.org/PL/Volume34/PSJ_12_2_Kazmierska.pdf.

Kaźmierska, K. (2016). Wywiad narracyjny - technika i pojęcia analityczne. W: R. Dopierała, K. Waniek (red.), Biografia i wojna. Łódź: Wydawnictwo Uniwersytetu Łódzkiego.

Kohli, M. (2012). Biografia: relacja, tekst, metoda. W: K. Kaźmierska (red.), Metoda biograficzna w socjologii. Antologia tekstów. Kraków: Wydawnictwo Nomos. 
Piorunek, M. (2016). Liczby i słowa w badaniach humanistycznych i społecznych. (Nie) dychotomiczność paradygmatów badawczych. W: M. Piorunek (red.), Badania biograficzne i narracyjne w perspektywie interdyscyplinarnej. Aplikacje-Egzemplifikacje - Dylematy metodologiczne. Poznań: Wydawnictwo Naukowe UAM.

Płatos, M. (2018). Autyzm odcieleśniony. Historia społecznego konstruowania autyzmu jako choroby, zaburzenia i niepełnosprawności. Annales Universitatis Paedagogicae Cracoviensis. Studia de Cultura, 10, s. 100-112. Pobrane z: http://studiadecultura. up.krakow.pl/article/view/4633/4349.

Płatos, M. (red.). (2016). Ogólnopolski Spis Autyzmu. Sytuacja młodzieży i dorosłych z autyzmem w Polsce. Warszawa: Stowarzyszenie Innowacji Społecznych „Mary i Max”. Pobrane z: http://www.spisautyzmu.pl/index_files/raport_OSA.pdf.

Rokuszewska-Pawełek, A. (1996). Miejsce biografii w socjologii interpretatywnej. Program socjologii biografistycznej FritzaSchutzego. ASK, 1, s. 37-54. Pobrane z: ttps://kb.osu. edu/bitstream/handle/1811/69470/ASK_1996n3_37_54.pdf?sequence=1.

Rynkiewicz, A., Łucka, I., Fryze M. (2012). Wysokofunkcjonujące dziewczęta z autyzmem i zespołem Aspergera - przyczyny rzadkiego diagnozowania, opis przypadków. Psychiatria, 2(9), s. 43-52. Pobrane z: journals.viamedica.pl.

Rzeźnicka-Krupa, J. (2007). Niepełnosprawność i świat społeczny. Szkice metodologiczne. Kraków: Oficyna Wydawnicza Impuls.

Rzeźnicka-Krupa, J. (2013). Niepełnosprawność intelektualna - narracje, reprezentacje, konteksty. Niepełnosprawność, 10, s. 85-111. Pobrane z: http://bazhum.muzhp.pl/ media//files/Niepelnosprawnosc/Niepelnosprawnosc-r2013-t-n10/Niepelnosprawnosc-r2013-t-n10-s85-111/Niepelnosprawnosc-r2013-t-n10-s85-111.pdf.

Schopler, E. (1996). Are autism and Asperger syndrome (AS) different labels or different disabilities? Journal of Autism Developmental Disorder, 26(1), s. 109-110.

Schütze, F. (2012). Analiza biograficzna ugruntowana empirycznie w autobiograficznym wywiadzie narracyjnym. Jak analizować autobiograficzne wywiady narracyjne. W: K. Kaźmierska (red.), Metoda biograficzna w socjologii. Antologia tekstów. Kraków: Wydawnictwo Nomos.

Sławińska, A. (2014). Zespół Aspergera u osób dorosłych - zbieżność z innymi zaburzeniami, zaburzenia współwystępujące i problemy towarzyszące. Psychiatria i Psychologia Kliniczna, 14, s. 304-307. Pobrane z: psjd.icm.edu.pl/psjd/element/bwmeta1.../c/ Psychiatria4.2014Slawinska_ZA.pdf.

Strauss, A.L. (2012). Transformacja tożsamości. W: K. Kaźmierska (red.), Metoda biograficzna w socjologii. Antologia tekstów. Kraków: Wydawnictwo Nomos.

Świtaj, P. (2009). Rola diagnozy psychiatrycznej w procesie stygmatyzacji osób z zaburzeniami psychicznymi. Postępy Psychiatrii i Neurologii, 18(4), s. 377-386. Pobrane z: ppn.ipin.edu.pl.

Treichel, B. (2012). Tożsamości biograficzne i zbiorowe w wywiadach narracyjnych. Przyczynek lingwistyczny. W: K. Kaźmierska (red.), Metoda biograficzna w socjologii. Antologia tekstów. Kraków: Wydawnictwo Nomos.

\section{Źródła internetowe}

http://www.autism.org.uk.

http://niegrzecznedzieci.org.pl/asperger/zrob-sobie-test-czy-jestes-z-kregu-aspi. 